For the City Yet to Come 

AbdouMaliq Simone

\section{For the City Yet to Come}

Changing African Life in Four Cities

Duke University Press Durham and London 2004 
(C) 2004 Duke University Press

All rights reserved

Printed in the United States of America

on acid-free paper $\infty$

Designed by $\mathrm{CH}$ Westmoreland

Typeset in Sabon with Helvetica Neue display

by Keystone Typesetting, Inc.

Library of Congress Cataloging-in-Publication

Data appear on the last printed page of

this book. 
For Karin, Zaira, and Na'ilah 
